\author{
Case Study \\ www.ijrap.net (ISSN:2229-3566)
}

\title{
THE EFFECT OF RASNAAMRITADI KASHAYAM IN GRIDHRASI: A CASE STUDY
}

Reshmi K Pillai ${ }^{1 *}$ and K Govindan Namboodiri ${ }^{2}$

${ }^{1}$ PG scholar, Department of Kayachikitsa, Sree Narayana Institute of Ayurvedic Studies and Research,

Pangode, Puthoor, Kollam, Kerala, India

${ }^{2}$ Professor and HOD, Department of Kayachikitsa, Sree Narayana Institute of Ayurvedic Studies and Research, Pangode, Puthoor, Kollam, Kerala, India

Received on: 28/06/20 Accepted on: 08/08/20

\author{
*Corresponding author \\ E-mail: reshmik10@gmail.com
}

DOI: 10.7897/2277-4343.1105132

\begin{abstract}
Gridhrasi is one of the 80 Nanatmaja Vata Vyadhi, which is caused by the aggravation of Vata Dosha; it can be divided into Vataja and Vatakaphaja. Gridhrasi can be equated with sciatica where pain, weakness, numbness and other discomfort along the path of sciatic nerve often accompanies with low back pain. In this study, 49 years old male patient complaints of low back pain radiating to both lower limb since one year, he was also complaining numbness on right lower limb. During clinical examination SLR test, Lasegue's sign were positive on both lower limbs. He was diagnosed as Gridhrasi. Patient was advice to take Rasnaamritadi Kashayam twice daily in a dose of $50 \mathrm{ml}$ one hour before meals. Rasnaamritadi Kashaya mentioned in Yoga amritam text Vata Vyadhi Chikitsa chapter. Drug mentioned in the yoga possess Vatahara, Kaphahara, Amapachana, Shoolahara and Shophahara property. After 30 days of treatment, he got $75 \%$ relief in low back pain and $90 \%$ relief in radiating pain and also there was an improvement in SLR and Lasegue's sign.
\end{abstract}

Keywords: Gridhrasi, sciatica, Rasnaamritadi Kashayam

\section{INTRODUCTION}

In the present era, Gridhrasi seems to be a common health issue which is occurring due to the lifestyle changes. As with the busy schedule of a common man, he cannot concentrate on his health. Improper handling and lifting of heavy objects, bike riding, improper exercises, accidental falls etc which leads to compression on lumber nerves or sacral nerves and cause sciatic pain. Gridhrasi is described under Vatavyadhi in Brihattrayi and Laghutrayi. Acharya Charaka included it as one among the 80 types of Nanatmajavatavyadhi ${ }^{1}$. Gridhrasi is characterized by pain starting from Sphik and radiate down words to Kati, Prushta, Uru, Janu, Jangha and Padam. In Vatakaphaja Gridhrasi, patient suffers from Dehasya Vakrata and also with Sphurana, Stambhana in Janu, Jangha and Uru. In Vatakaphaja Gridhrasi, patient suffers from Tandra, Gourava and Arocaka ${ }^{2}$. Gridhrasi can be correlated with Sciatica in modern medicine. It is a very painful condition where pain starts from the lumbar region and radiate to the buttock, thigh, calf and foot ${ }^{3}$. Sciatica is a relatively common condition with a lifetime incidence varying from $13 \%$ to $40 \%$. The corresponding annual incidence of an episode of Sciatica ranges from $1 \%$ to $5 \%{ }^{4}$ In modern medicine, administration of muscle relaxants, NSAID's, Opioids, Corticosteroids, Gabapentin etc gives only temporary relief from pain. The continuous use of such medicine causes gastritis, kidney and liver disorders. Low to moderate quality evidence suggests that spinal manipulation is an effective treatment for acute Sciatica and however for chronic Sciatica the evidence is poor $^{5}$. Rasnaamritadi Kashaya is a formulation from Yoga amritam Vata Vyadhi Chikitsa which contains Rasna, Guduchi, Shunthi, Eranda, Bala, Gokshura, Punarnava, Devadaru. ${ }^{6}$ Here all content of the Kashaya having Ushna, Ruksha, Deepana Pachana and Kapha Vata Shamana properties.

\section{MATERIAL AND METHODS}

\section{Place of Study}

Sree Narayana Institute of Ayurvedic Studies and Research, Pangode, Puthoor, Kollam

\section{Ethical Clearance}

The study has been cleared by IEC vide approval reference number IEC/SNIASR2018041810. The study is carried out as per international conference of harmonization-good clinical practice guidelines (ICH-GCP)

\section{Case presentation}

49 years old male patient, office attender by occupation reported to Kayachikitsa OPD, Sree Narayana Institute of Ayurvedic Studies and Research, Pangode on 04-05-2019 with complaints of low back pain radiating to the posterior aspect of both lower limbs along with difficulty in bending forward since one year and also complaint numbness of right lower limb.

\section{History of presenting complaint}

Patient was apparently asymptomatic before one year, gradually developed pain in lower back region which started to radiate posterior aspect of both lower limbs. It got aggravated by prolonged sitting and standing.

Before six months back, pain get worse and he took pain killers for a period of one month which gave symptomatic temporary relief. Before one-month back pain reoccurred and which was 
continuous in nature. Later he came to Sree Narayana Institute of Ayurvedic Studies and Research for a better cure.

\section{History of past illness}

Not a known case of diabetics, hypertension and dyslipidemia.

\section{Personal history}

Table 1: Personal History

\begin{tabular}{|c|c|}
\hline Appetite: poor, but takes food regularly & Bowel: constipated \\
\hline Diet: non- vegetarian diet prefers fired item, pickles, etc. & Bladder: normal \\
\hline Allergy: not detected & Sleep: disturbed due to pain, since 1 month \\
\hline Addiction: nil & Exercise: moderate \\
\hline
\end{tabular}

\section{Examinations}

Gait: Antalgic gait

\section{Spine examination}

Inspection: no visible deformity

Palpation: tenderness L4-L5, L5-S1 region

\section{Lumbar spine}

Flexion: not possible

Extension: restricted due to pain

Lateral bending: restricted due to pain

Straight leg raise test positive on right lower limb at 35 degrees

and left lower limb on 30 degrees

Lasegue's sign positive on both lower limbs.

\section{Radiological investigations}

X-ray of LS spine AP and lateral view on 04-05-2019

Space reduction on L3-L4, L4-L5, L5-S1 level

\section{Treatment}

The patient was advised to take $50 \mathrm{ml}$ of Rasnaamritadi Kashayam twice daily one hour before meals continuously for a period of 30 days.

\section{Grading parameter}

Ruk (Pain)

No pain -0

Painful, walks without limping -1

Painful, walks with limping but without support -2

Painful, can walk only with support -3

Painful, unable to walk -4

\section{RESULT AND DISCUSSION}

Table 2: Subjective parameter

\begin{tabular}{|c|c|c|}
\hline Symptoms & Before treatment & After treatment \\
\hline Ruk & Grade 2 & Grade 1 \\
\hline Toda & Grade 3 & Grade 0 \\
\hline Stambha & Grade 2 & Grade 1 \\
\hline Spandan & Grade 3 & Grade 1 \\
\hline
\end{tabular}

\section{Toda (Pricking sensation)}

No pricking sensation - 0

Occasional pricking sensation - 1

Mild pricking sensation - 2

Moderate pricking sensation - 3

Severe pricking sensation -4

\section{Stambha (Stiffness)}

No stiffness - 0

Sometimes for 5-10 minutes - 1

Daily for 10-30 minutes - 2

Daily for 30-60 minutes - 3

Daily for more than 1 hour - 4

\section{Spandan (Twitching)}

No Twitching Sometimes for 5-10 minutes - 1

Daily for 10-30 minutes - 2

Daily for 30-60 minutes - 3

Daily for more than 1 hour - 4

\section{Sakthnah Kshepum Nigrahaniyat (S.L.R Test)}

More than 90 degree - 0

71 degree-90 degree -1

51 degree-70 degree - 2

31 degree-50 degree - 3

Up to 30 degree - 4

\section{Tenderness}

No tenderness - 0

Tenderness to palpation without grimace - 1

Tenderness with grimace or flinch on palpation - 2

Tenderness with withdrawal - 3

Jump sign to non-noxious stimuli - $4^{7,8}$

Table 4: Lasegue's sign

Table 3: Straight Leg Raising test (SLR)

\begin{tabular}{|c|c|c|}
\hline & Before treatment & After treatment \\
\hline Right & Active 35 degree & 60 degree \\
\hline & Passive 45 degree & 65 degree \\
\hline Left & Active 30 degree & 70 degree \\
\hline & Passive 45 degree & 75 degree \\
\hline
\end{tabular}

\begin{tabular}{|c|c|c|}
\hline & Before treatment & After treatment \\
\hline Right lower limb & Positive & negative \\
\hline Left lower limb & Positive & Negative \\
\hline
\end{tabular}


Before treatment he has grade 2 Ruk, grade 2 Toda, grade 2 Stambha and grade 3 Spandan. After the completion of 30 days treatment it change to grade 1 Ruk, Stambha, Spandan respectively and Toda change to Grade 0 . Most of the drug in Rasnaamritadi Kashayam show Agni Deepana, Amapachana, Kapha Vata Shamaka properties. So, it acts as Shoolahara and Shophahara to a great extent. By the combined effect of these properties, Rasnaamritadi Kashayam is Kapha Vata Shamaka at same time. The ingredients such as Bala, Rasna, Guduchi and Punarnava have the properties of Rasayana so it will help in restoring the strength of vertebral column as well as the nerve roots. This helps to prevent the Punaruthbhava of the disease; hence it helps in reducing the symptoms of Gridhrasi.

\section{CONCLUSION}

Management of Gridhrasi with Rasnaamritadi Kashayam shows a good result in the subjective and objective parameters of the study.

Hence Rasnaamritadi Kashayam has a significant role in the management of Gridhrasi.

\section{REFERENCES}

1. Singh R H. Charaka Samhita Sutra sthana of Agnivesha (Ayurveda Dipika, Chakrapani Dutta, commentary, Sanskrit) Varanasi: Chaukhambha Orientalia; 1941. p. 113.20/11.
2. Singh R H. Charaka Samhita Chikitsa sthana of Agnivesha (Ayurveda Dipika, Chakrapani Dutta, commentary, Sanskrit) Varanasi: Chaukhambha Orientalia; 1941. p. 619.28/ 57.

3. Brian Walker R, Nicki Colledge R, Stuart Ralston H, Ian Penman D. Davidson's Principles and Practice of Medicine. $22^{\text {nd }}$ ed. UK: Elsevier Health; 2014. p. 1220.

4. Stafford M A, Peng P, Hill D A. Sciatica: A review of history, epidemiology, pathogenesis and the role of epidural steroid injection in management (internet) British Journal of Anaesthesia; 2007 August 17 available from: https://academic.oup.com/bja/article/99/4/461/305514.

5. www.medscape.com/medline Sciatica: a review of history epidemiology, Pathogenesis accessed on 3/5/17

6. Ravi Varma I.A. Yogamrta. $4^{\text {th }}$ ed. Trivandrum: Government of Kerala; 1960. p. 163.

7. Suke Dipali Uttamrao. The study of Gridhrasi According to Chakrapanidatta and its Management by Panchamuli Kashaya with Eranda Taila. Ayurveda and Siddhanta Govt. Ayurveda College, Nanded, Maharashtra; 2017.

8. https://chiro.org/LINKS/grading.shtml accessed on 3/5/17

\section{Cite this article as:}

Reshmi K Pillai and K Govindan Namboodiri. The effect of Rasnaamritadi Kashayam in Gridhrasi: A Case Study. Int. J. Res. Ayurveda Pharm. 2020;11(5):15-17 http://dx.doi.org/ $\underline{10.7897 / 2277-4343.1105132}$ the site content and articles published. The views expressed in articles by our contributing authors are not necessarily those of IJRAP editor or editorial board members. 